\title{
PERLINDUNGAN HUKUM BAGI PENGGUNA JASA ANGKUTAN UDARA PADA PENERBANGAN DOMESTIK
}

\author{
Sudiarto \\ Fakultas Hukum Universitas Mataram, \\ Lombok, NTB, Indonesia \\ Email: sudiartomataram@gmail.com \\ Hasan Asy'ari \\ Fakultas Hukum Universitas Mataram, \\ Lombok, NTB, Indonesia \\ Email: hasanasyari700@gmail.com
}

\begin{abstract}
Abstrak
Tujuan penelitian ini dalah untuk mengkaji dan menganalisis perlindungan hukum bagi pengguna jasa angkutan udara atau konsumen pada penerbangan domestik. Metode yang digunakan adlaah metode normatif dengan pendekatan peraturan perundang-undangan dan konseptual. Adapun hasil penelitian ini ditemukan bahwa peraturan mengenai pemberian fasilitas khusus bagi penyandang cacat, lanjut usia, anak dibawah usia 12 (dua belas) tahun serta orang sakit tidak ditemukan dalam penerbangan domestik di Indonesia. Prosedur untuk mendapatkan ganti kerugian kepada penumpang yang meninggal dunia akibat kecelakaan pesawat udara sangat berbelit-belit. Selain itu hasil ganti kerugian kepada penumpang yang disebabkan karena keterlambatan penerbangan belum optimal dilaksanakan.
\end{abstract}

\section{Kata kunci: Perlindungan Hukum; Angkutan Udara; Konsumen.}

\begin{abstract}
The purpose of this study is to study and analyze legal protection for air transport service users or consumers on domestic flights. The method used is the normative method with the statutory and conceptual approach. The results of this study found that regulations regarding the provision of special facilities for people with disabilities, the elderly, children under the age of 12 (twelve) years and the sick are not found in domestic flights in Indonesia. The procedure for obtaining compensation to passengers who died as a result of an airplane accident is very complicated. In addition, the results of compensation to passengers caused by flight delays have not been optimally implemented.
\end{abstract}

\section{Keywords: Legal Protection; Air transport; Consumer.}

\section{A. PENDAHULUAN}

Secara geografis, berdasarkan luas wilayah dan penyebaran penduduknya, peranan dan fungsi angkutan udara di Indonesia mempunyai posisi yang sangat penting dan juga strategis, baik ditinjau dari segi kesatuan dan persatuan nasional, kehidupan sosial budaya, ekonomi, roda pemerintahan maupun pertahanan dan keamanan. Angkutan udara merupakan satusatunya alternatif yang cepat, efesien serta ekonomis bagi pengangkutan antar pulau dan antar daerah di Indonesia. ${ }^{1}$

Disamping itu, angkutan udara juga merupakan sarana penting bagi pengembangan pariwisata, mengingat Indonesia sebagai satu diantara beberapa negara yang kaya akan kebudayaan dan keindahan alamnya yang menarik dan iklim tropisnya dapat menarik wisatawan asing sehingga mendatangkan devisa negara sebagai pengganti minyak bumi yang

${ }^{1}$ Sudiarto.(2012). "Tanggung Gugat Pemerintah Terhadap Kecelakaan Pesawat Udara di Indonesia” Jurnal Ilmu Hukum Universitas Hassanuddin Makassar Amanna Gappa, 20(3):273. 
kian merosot. Peranan dan fungsi angkutan udara yang sangat penting ini, terutama ditinjau dari segi politik dan ekonomi telah menyebabkan perkembangan yang sangat pesat terhadap dunia penerbangan nasional khususnya penumpang.

Perhatian yang dimaksud adalah berupa pelayanan yang baik, mengingat moda angkutan ini membutuhkan biaya besar, baik untuk mendirikan maskapai penerbangan, mengoperasikannya maupun untuk pengguna jasa angkutan juga membutuhkan biasa yang cukup besar agar dapat menggunakan moda angkutan ini. Pelayanan yang dibutuhkan oleh pengguna jasa angkutan udara adalah:

a) berkaitan dengan pelayanan yang baik; dan

b) hak untuk mendapatkan ganti rugi jika mengalami kerugian.

Kedua bentuk pelayanan yang dibutuhkan oleh pengguna jasa angkutan udara tersebut merupakan kebutuhan hakiki yang harus dipenuhi oleh pihak pengangkut udara. Penumpang dalam hal ini dengan perusahaan pengangkut/perusahaan penerbangan memiliki hubungan hukum pelaku usaha dan konsumen sebagaimana yang diatur dalam Undang-undang No. 8 Tahun 1999 Tentang Perlindungan Konsumen yang kemudian disingkat dengan (UUPK), yang sebenarnya konsumen memiliki hak dalam peristiwa pengangkutan antara pelaku usaha dan konsumen. Secara umum, konsumen memiliki 4 hak yang telah berlaku universal, yaitu: ${ }^{2}$

1) Hak untuk mendapatkan keamanan;

2) Hak untuk mendapatkan informasi;

3) Hak untuk memilih

4) Hak untuk didengar.

Keempat hak tersebut merupakan hak yang kemudian diadopsi dalam Pasal 4 UUPK yang mengatur hak-hak konsumen, antara lain: ${ }^{3}$

a) Hak atas kenyamanan, keamanan, dan keselamatan dalam mengkonsumsi barang dan/ atau jasa.

b) Hak untuk memilih barang dan/atau jasa serta mendapatkan barang dan atau jasa tersebut sesuai dengan nilai tukar dan kondisi serta jaminan yang dijanjikan.

c) Hak atas informasi yang benar, jelas, dan jujur mengenai kondisi dan jaminan barang dan/atau jasa.

d) Hak untuk didengar pendapat dan keluhannya atas barang dan atau jasa yang digunakan.

e) Hak untuk mendapatkan advokasi, perlindungan, dan upaya penyelesaian sengketa perlindungan secara patut.

f) Hak untuk mendapatkan pembinaan dan pendidikan konsumen.

g) Hak untuk diperlakukan atau dilayani secara benar dan jujur serta tidak diskriminatif.

h) Hak untuk mendapatkan kompensasi, ganti rugi dan/atau penggantian, apabila barang dan/atau jasa yang diterima tidak sesuai dengan perjanjian atau tidak sebagaimana mestinya.

${ }^{2}$ Sidharta.(2000). Hukum Perlindungan Konsumen Indonesia. Jakarta: PT. Grasindo, hlm. 34.

${ }^{3}$ Ibid.

318 Sudiarto \& Hasan Asy’ari | Perlindungan Hukum Bagi Pengguna Jasa.... 
i) Hak-hak yang diatur dalam ketentuan peraturan perundang- undangan lainnya.

Hak-hak konsumen yang diatur dalam Undang-Undang Nomor 8 Tahun 1999 tentang Perlindungan Konsumen tersebut diaplikasikan dalam Undang-Undang Nomor 1 Tahun 2009 tentang Penerbangan. Dalam Undang-Undang tersebut diatur mengenai hak penumpang ${ }^{4}$ sebagai $^{2}$ pengguna jasa angkutan, namun tidak dijelasksn secara terperinci bagaimana perlindungan secara menyeluruh tentang konsumen pengguna jasa angkutan udara dalam banyak hal diantaranya seperti fasilitas pengguna jasa disabilitas, serta hal-hal lain yang kemudian dalam undang-undang disebutkan namun konsumen seolah-olah tidak memiliki kekuatan jika hal tersebut dilanggar. Untuk pengguna jasa penyandang disabilitas umpamanya tidak ditemukan satupun pesawat udara yang melayani route domestik yang menyediakan tempat khusus bagi penyandang disabilitas sebagaimana ditentukan peraturan perundang-undangan. Kenyataan ini menunjukkan bahwa konsumen moda angkutan berada dalam posisi lemah dan dirugikan. ${ }^{5}$

Kasus gugatan yang dilakukan oleh Ridwan Sumantri salah seorang penyandang disabiltas terhadap PT Lion Mentari sbegai tergugat I, PT Angkasa Pura II sebagai Tergugat II dan Kementerian Perhubungan Republik Indonesia sebagai Tergugat III, pada tahun 2011 menjadi bukti nyata mengenai ketidak pedulian pengangkut udara terhadap hak-hak yang seharusnya diterima oleh penyandang disabilitas. Putusan Mahkamah Agung Nomor 231/Pdt.G/2011/ PN.Jkt.Pst yang menyatakan bahwa tindakan Tergugat I, Tergugat II dan Tergugat III yang tidak menyediakan fasilitas untuk penyandang disabilitas merupakan perbuatan melanggar hokum.

\section{B. METODE PENELITIAN}

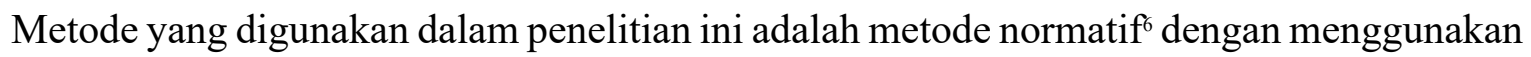
pendekatan peraturan perundang-undangan dan pendekatan konseptual. ${ }^{7}$ Jenis data berupa bahan hukum primer terdiri dari Undang-undang Nomor 8 Tahun 1999 Tentang Perlindungan Konsumen, Undang-undang Nomor 1 Tahun 2009 Tentang Penerbangan dan Peraturan Menteri Perhubungan Republik Indonesia Nomor 77 Tahun 2011 Tentang Tanggung Jawab Pengangkut Angkutan Udara. Bahan hukum skunder dalam penelitian ini berupa pendapat para ahli hukum dan bahan non hukum adalah berupa Kamus Penerbangan. Teknik pengumpulan bahan hukum dilakukan dengan melakukan penelusuran literatur dan studi lapangan.

\section{PEMBAHASAN}

Landasan pijak perlindungan hukum bagi rakyat (masyarakat atau konsumen/pengguna jasa) di Indonesia adalah Pancasila dan UUD negara Republik Indonesia Tahun 1945 (UUD NRI 1945), karena merupakan dasar idiologi dan falsafah bangsa Indonesia yang menjunjung tinggi nilai-nilai kemanusiaan dengan menempatkan hukum sebagai panglima dan bukan kekuasaan. Penghormatan terhadap hak-hak asasi manusia dan memposisikan bangsa Indonesia sebagai negara hukum menimbulkan konsekuensi yang harus ditaati dan dilaksanakan oleh pemerintah sebagai penyelenggara negara.

AZ. Nasution", mengartikan perlindungan konsumen sebagai "keseluruhan asas-asas dan kaidah-kaidah yang mengatur dan melindungi konsumen dalam hubungan dan masalahnya dengan para penyedia barang dan/ atau jasa konsumen." Selanjutnya Az. Nasution menyatakan

\footnotetext{
227.

${ }^{4}$ Yusuf Shofie.(2009). Perlindungan Konsumen \& Instrumen Instrumen Hukumnya. Bandung: Citra Aditya Bakti, hlm. ${ }^{5}$ Ibid.

${ }^{6}$ Mukti Fajar dan Yulianto Achmad.(2010). Dualisme Penelitian Hukum, Normatif \& Empiris. Yogjakarta: Pustaka Pelajar, hlm. 153.

${ }^{7}$ Peter Mahmud Marzuki.(2008). Penelitian Hukum. Jakarta: Kencana Prenada Media Group, hlm. 93

${ }^{8}$ Az Nasution.(1999). Perlindungan Konsumen, Suatu Pengantar. Jakarta: Daya Widya, hlm. 3
} 
bahwa hukum perlindungan konsumen merupakan bagian dari hukum konsumen yang memuat asas-asas atau kaidah-kaidah bersifat mengatur, dan juga mengandung sifat yang melindungi kepentingan konsumen. Adapun hukum konsumen diartikan sebagai keseluruhan asas-asas dan kaidah-kaidah hukum yang mengatur hubungan dan masalah antara berbagai pihak satu sama lain berkaitan dengan barang dan atau jasa konsumen, di dalam pergaulan hidup. ${ }^{9}$ Pengertian yang dikemukakan oleh para ahli ini dipertegas dalam Pasal 1 angka 1 UUPK, bahwa Perlindungan Konsumen adalah segala upaya yang menjamin adanya kepastian hukum untuk memberi perlindungan kepada konsumen.

Salah satu fungsi hukum adalah untuk memberikan perlindungan kepada warga masyarakat, terutama yang berada pada posisi yang lemah akibat hubungan hukum yang tidak seimbang. Demikian halnya dengan Hukum Perlindungan Konsumen untuk melindungi konsumen dari pelaku usaha yang tidak jujur.

Perlindungan Konsumen adalah segala upaya yang menjamin adanya kepastian hukum untuk memberi perlindungan kepada konsumen. Sedangkan Hukum Perlindungan Konsumen adalah keseluruhan asas-asas dan kaidah-kaidah yang mengatur dan melindungi konsumen dalam hubungan dan masalah penyediaan dan penggunaan produk konsumen antara penyedia dan penggunanya dalam kehidupan bermasyarakat.

Mengenai pelaku usaha, masyarakat umum biasanya menyebut pelaku usaha dengan sebutan produsen. Kadang-kadang mereka mengartikan produsen sebagai pengusaha, namun ada pula pendapat yang mengatakan bahwa produsen hanya penghasil barang saja dan merupakan salah satu unsur dari pengusaha. Sementara dalam Undang-undang Nomor 8 Tahun 1999 Tentang Perlindungan Konsumen digunakan istilah Pelaku Usaha. Pasal 1 Angka 3 UUPK, pengertian Pelaku usaha dirumuskan sebagai berikut "Setiap orang perorangan atau badan usaha, baik yang berbentuk badan hukum maupun bukan badan hukum yang didirikan dan berkedudukan di wilayah hukum negara Republik Indonesia, baik sendiri mapun bersama-sama melalui perjanjian penyelenggaraan kegiatan usaha dalam berbagai bidang ekonomi”.

Pengguna jasa merupakan sebutan lain bagi konsumen yang khusus ditujukan bagi pengguna moda angkutan, baik angkutan darat, laut maupun udara. Karena merupakan nama lain dari konsumen, maka hak-hak konsumen yang diatur di dalam Undang Undang Nomor 8 Tahun 1999 Tentang Perlindungan Konsumen berlaku juga bagi pengguna jasa angkutan di Indonesia.

Hak konsumen yang diatur di dalam Undang-undang Perlindungan Konsumen (UUPK) terdapat di dalam Pasal 4 yang berbunyi

1. hak atas kenyamanan, keamanan, dan keselamatan dalam mengkonsumsi barang dan/ atau jasa;

2. hak untuk memilih barang dan/atau jasa serta mendapatkan barang dan/atau jasa tersebut sesuai dengan nilai tukar dan kondisi serta jaminan yang dijanjikan;

3. hak atas informasi yang benar, jelas, dan jujur mengenai kondisi dan jaminan barang dan/atau jasa;

4. hak untuk didengar pendapat dan keluhannya atas barang dan/atau jasa yang digunakan;

5. hak untuk mendapatkan advokasi, perlindungan, dan upaya penyelesaian sengketa perlindungan konsumen secara patut;

6. hak untuk mendapat pembinaan dan pendidikan konsumen;

7. hak untuk diperlakukan atau dilayani secara benar dan jujur serta tidak diskriminatif; 
8. hak untuk mendapatkan kompensasi, ganti rugi dan/atau penggantian, apabila barang dan/atau jasa yang diterima tidak sesuai dengan perjanjian atau tidak sebagaimana mestinya;

9. hak-hak yang diatur dalam ketentuan peraturan perundang-undangan lainnya.

Hak-hak pengguna jasa angkutan udara terakhir sekali diatur dalam Undang-undang Nomor 1 Tahun 2009 Tentang Penerbangan, dimana hak-hak pengguna jasa angkutan adalah berupa Hak untuk mendapatkan pelayanan.

Undang-Undang Nomor 1 Tahun 2009 Tentang Penerbangan yang terdapat dalam Pasal 97 mengatur tentang pelayanan angkutan udara. Pelayanan angkutan udara di Indonesia dibagi menjadi 3 (tiga) bagian, yakni:

a. Pelayanan dengan standar maksimum (full services); adalah bentuk pelayanan maksimum yang diberikan kepada penumpang selama penerbangan sesuai dengan jenis kelas pelayanan penerbangan.

b. Pelayanan dengan standar menengah (medium service); yaitu bentuk pelayanan sederhana yang diberikan kepada penumpang.

c. Pelayanan dengan standar minimum (no frills) merupakan bentuk pelayanan minimum yang diberikan kepada penumpang.

Selain mendapatkan pelayanan sebagaimana dimaksudkan pada Pasal 97 tersebut, pelayanan yang layak juga diberikan kepada pengguna jasa angkutan untuk penyandang cacat, lanjut usia, anak-anak dan/atau orang sakit sebagaimana diatur pada Pasal 134 Undang-undang Nomor 1 Tahun 2009 Tentang Penerbanagan berhak memperoleh pelayanan perlakuan dan fasilitas khusus berupa:

a) Pemberian prioritas tambahan tempat duduk;

b) Penyediaan fasilitas kemudahan untuk naik ke dan turun dari pesawat udara;

c) Penyediaan fasilitas untuk penyandang cacat selama berada di pesawat udara;

d) Sarana bantu bagi orang sakit;

e) Penyediaan fasilitas untuk anak-anak selama berada di pesawat udara;

f) Tersedianya personil yang dapat berkomunikasi dengan penyandang cacat, lanjut usia, anak-anak, dan/atau orang sakit; dan

g) Tersedianya buku petunjuk tentang keselamatan dan keamanan penerbangan bagi penumpang pesawat udara dan sarana lain yang dapat dimengerti oleh penyandang cact, lanjut usia, dan orang sakit;

Selain pasal-pasal tersebut di atas, yang menjadi hak bagi pengguna jasa angkutan udara terdapat di dalam Pasal 140 Undang-undang Penerbangan yang pada intinya mewajibkan bagi pihak pengangkut udara memberikan pelayanan yang layak terhadap setiap pengguna jasa angkutan udara.

Selain mendapatkan hak pelayanan dari pihak pengangkut udara, pengguna jasa angkutan juga mendapatkan hak untuk mendapatkan ganti kerugian dari pihak pengangkut apabila pengguna jasa angkutan mengalami kerugian akibat kesalahan pengangkut udara. Ganti kerugian pihak pengangkut ini merupakan bentuk tanggung jawab yang harus dilakukan oleh pihak pengangkut udara atas kerugian yang dialami penumpang. 
Mengenai tanggung jawab (beberapa literatur menggunakan istilah tanggung gugat sebagai terjemahan dari liability, termasuk dalam tulisan ini mengunakan istilah tanggung gugat $)^{10}$ pengangkut udara ini dikenal beberapa prinsip tanggung gugat. Prinsip tanggung gugat merupakan perihal yang sangat penting dalam hukum perlindungan konsumen (dalam tulisan ini menggunakan istilah pengguna jasa angkutan sebagai padanan kata konsumen). Secara umum, prinsip-prinsip tanggung gugat dalam hukum dapat dibedakan sebagai berikut:

1) Kesalahan (liability based on fault), Fault liability atau liability based on fault ${ }^{11}$ adalah prinsip yang cukup umum berlaku dalam hukum pidana dan perdata. Prinisp ini menyatakan, seseorang baru dapat dimintakan pertanggung gugatannya secara hukum jika ada unsur kesalahan yang dilakukannya. "Yang dimaksud kesalahan adalah unsur yang bertentangan dengan hukum. Pengertian "hukum", tidak hanya bertentangan dengan undang-undang, tetapi juga kepatutan dan kesusilaan dalam masyarakat". Secara common sense, asas tanggung gugat ini dapat diterima karena adalah adil bagi orang yang berbuat salah untuk mengganti kerugian bagi pihak korban, dan sangat tidak adil jika orang yang tidak bersalah harus mengganti kerugian yang diderita orang lain.

2) Praduga selalu bertanggung gugat (presumption of liability); ${ }^{12}$ Prinsip ini menyatakan, tergugat selalu dianggap bertanggung gugat, sampai ia dapat membuktikan, ia tidak bersalah. Jadi, beban pembuktian ada pada tergugat.

3) Prinsip Tanggung Jawab Mutlak, ${ }^{13}$ di dalam kepustakaan biasa dikenal dengan ungkapan absoluter liability dimaksudkan tanggung gugat semacam ini tanpa keharusan untuk membuktikan adanya kesalahan, atau dengan perkataan lain, suatu prinsip tanggung gugat yang memandang kesalahan sebagai suatu yang tidak relevan untuk dipermasalahkan apakah pada kenyataanya ada atau tidak.

Berkaiatan dengan prinsip tanggung gugat ini, dalam doktrin hukum pengangkutan khususnya, dikenal empat variasi:

1) Pengangkut dapat membebaskan diri dari tanggung gugat kalau ia dapat membuktikan, kerugian ditimbulkan oleh hal-hal di luar kekuasaannya;

2) Pengangkut dapat membebaskan diri dari tanggung gugat, jika ia dapat membuktikan, ia mengambil suatu tindakan yang diperlukan untuk menghindari timbulnya kerugian;

3) Pengangkut dapat membebaskan diri tanggung gugat jika ia dapat membuktikan, kerugian yang timbul bukan karena kesalahannya;

4) Pengangkut tidak bertanggung gugat jika kerugian itu ditimbulkan oleh kesalahan/kelalaian penumpang atau karena kualitas/mutu barang yang diangkut tidak baik.

Tampak beban pembuktian terbalik (omkering van bewijslast) diterima dalam prinsip tersebut. Dasar pemikiran dari teori pembalikan beban pembuktian adalah seseorang dianggap bersalah, sampai yang bersangkutan dapat membuktikan sebaliknya. Ini sangat bertentangan dengan asas hukum praduga tak bersalah (presumption of innocence) yang lazim dikenal dalam hukum. Namun, jika diterapkan alam kasus pengguna jasa angkutan akan tampak, asas demikian cukup relevan. Jika diterapkan prinsip ini, maka yang berkewajiban untuk membuktikan

\footnotetext{
${ }^{10}$ Sudiarto.(2012). "Tanggung Gugat Pengangkut Terhadap Penumpang Dalam Kecelakaan Pesawat Udara Pada Penerbangan Domestik" Universitas Airlangga Disertasi, hlm. 24

${ }^{11}$ Endang Saefullah Wiradipradja.(1989). Tanggung Jawab Pengangkut dalam Hukum Pengangkutan Udara Internasional dan Nasional. Yogyakarta: Liberty, hlm. 20

${ }^{12}$ Ibid., hlm. 28

${ }^{13}$ Ibid., hlm. 35
}

322 Sudiarto \& Hasan Asy’ari | Perlindungan Hukum Bagi Pengguna Jasa.... 
kesalahan itu ada di pihak pelaku usaha (pengangkut udara) yang digugat. Beban pembuktian (burden of proof) ${ }^{14}$ dalam transportasi udara perusahaan penerbangan mempunyai kewajiban membuktikan tidak bersalah yang dikenal sebagai beban pembuktian terbalik.

Selain hak untuk mendapatkan ganti rugi, pengguna jasa angkutan udara juga berhak untuk meminta tanggung gugat pengangkut disebabkan karena keterlambatan diangkut oleh moda angkutan pengangkut. Demikian juga dengan tidak terangkutnya pengguna jasa oleh pengangkut dengan alasan kapasitas pesawat udara. Dalam hal ini pihak pengangkut harus memberikan kompensasi kepada pengguna jasa berupa: ${ }^{15}$

a. Mengalihkan ke penerbangan lain tanpa membayar biaya tambahan; dan/atau

b. Memberikan konsumsi, akomodasi, dan biaya transportasi apabila tidak ada penerbangan lain ke tempat tujuan.

Berkaitan dengan tanggung jawab (tanggung gugat) pengangkut udara di Indonesia, sebagai acuannya adalah Undang-undang Nomor 1 Tahun 2009 Tentang Penerbangan yang mengatur tentang tanggung jawab pengangkut terhadap penumpang dari Pasal 141, Pasal 146 dan Pasal147. Pasal 141 mengatur tentang tanggung jawab pengangkut udara atas kerugian penumpang yang meninggal dunia, cacat tetap, atau luka-luka yang diakibatkan kejadian angkutan udara di dalam pesawat dan/atau naik turun pesawat udara.

Pasal 146 Undang-undang Nomor 1 Tahun 2009 mengatur mengenai tanggung jawab pengangkut udara atas kerugian yang diderita karena keterlambatan pada angkutan penumpang, bagasi atau kargo, kecuali apabila pengangkut dapat membuktikan bahwa keterlambatan tersebut disebabkan oleh fackor cuaca dan teknis operasional. Sedangkan Pasal 147 mengatur tentang tanggung jawab pengangkut udara atas tidak terangkutnya penumpang, sesuai dengan jadwal yang telah ditentukan dengan kapasitas pesawat udara. Bentuk tanggung jawab pengangkut udara tersebut berupa mengalihkan ke penerbangan lain tanpa membayar biaya tambahan; dan/atau memberikan konsumsi, akomodasi, dan biaya transportasi apabila tidak ada penerbangan lain ke tempat tujuan.

Pelaksanaan dari Undang-undang Nomor 1 Tahun 2009 Tentang Penerbangan tersebut, khususnya terhadap tanggung jawab pengangkut udara, Pemerintah Republik Indonesia dalam hal ini Menteri Perhubungan Republik Indonesia pada tanggal 8 Agustus 2011 mengeluarkan Peraturan Menteri Perhubungan Nomor 77 Tahun 2011 Tentang Tanggung Jawab Pengangkut Angkutan Udara. Ketentuan-ketentuan yang terdapat di dalam Pasal 141, 146 dan 147 Undangundang Nomor 1 Tahun 2009 terlaksana di dalam Pasal 3, pasal 9, pasal 10, pasal 11, pasal 12, dan pasal 13 Peraturan Menteri Perhubungan Republik Indonesia Nomor 77 Tahun 2011 tersebut.

Implementasi Pasal 141 Undang-undang Nomor 1 Tahun 2009 terdapat di dalam Pasal 3 Peraturan Menteri Perhubungan Republik Indonesia menyatakan bahwa untuk kerugian bagi penumpang yang meninggal dunia di dalam pesawat udara karena kecelakaan pesawat udara atau kejadian semata-mata ada hubungannya dengan pengangkutan udara diberikan ganti kerugian sebesar Rp 1.250.000.000,- (satu milyar dua ratus lima puluh juta rupiah) per penumpang.

Penumpang yang meninggal dunia pada saat proses embarkasi dan disembarkasi, baik di bandara tujuan maupun di bandara transit diberikan ganti kerugian sebesar Rp 500.000.000,(lima ratus juta rupiah). Bagi penumpang yang mengalami cacat tetap diberikan ganti kerugian sebesar Rp 1.250.000.000,- (satu milyar dua ratus lima puluh juta rupiah) per penumpang.,

\footnotetext{
${ }^{14}$ Martono.(2007). Kamus Hukum dan Regulasi Penerbangan. Jakarta: Raja Grafindo Persada, hlm. 38
}

${ }^{15}$ Pasal 147 ayat (2) Undang-undang Nomor 1 Tahun 2009 Tentang Penerbangan. 
sedangkan bagi enumpang yang mengalami luka-luka diberikan ganti kerugian sebesar biaya perawatan yang nyata dan paling tinggi Rp 200.000.000,- (dua ratus juta rupiah).

Ketentuan dalam Pasal 146 dan Pasal 147 Undang-undang Nomor 1 Tahun 2009 Tentang Penerbangan, dapat dilihat implementasinya di dalam Pasal 9, 10, 11, 12 dan Pasal 13 Peraturan Menteri Perhubungan Republik Indonesia Nomor 77 Tahun 2011 Tentang Tanggung Jawab Pengangkut Angkutan Udara.

Pasal 9 pada intinya mengatur tentang keterlambatan angkutan udara terdiri dari flight delayed, denied boarding passanger, dan cancelation of flight. Jumlah ganti kerugian untuk penumpang disebabkan karena flight delayed empat jam atau lebih sebesar Rp. 300.000,(tiga ratus ribu rupiah) per penumpang. Untuk keterlambatan disebabkan karena denied boarding passanger, pengangkut wajib mengalihkan ke penerbangan lain tanpa membayar biaya tambahan dan/atau memberikan konsumsi, akomodasi, dan biaya transportasi apabila tidak ada penerbangan lain ke tempat tujuan. Sedangkan bagi penumpang yang mengalami cancelation of flight diatur dalam Pasal 12 yang pada intinya mengatur apabila pembatalan penerbangan, pengangkut wajib memberitahukan kepada penumpang paling lambat 7 (tujuh) hari kalender sebelum pelaksanaan penerbangan dengan mengembalikan seluruh uang tiket yang telah dibayarkan oleh penumpang.

Pasal 13 Peraturan Menteri Perhubungan Republik Indonesia Nomor 77 Tahun 2011 mengatur mengenai pembebasan pengangkut udara atas ganti kerugian akibat keterlambatan penerbangan apabila disebabkan karena faktor cuaca dan/atau teknis operasional. Faktor cuaca antara lain berupa hujan lebat, petir, badai, kabut, asap, jarak pandang di bawah standar yang mengganggu keselamatan penerbangan. Sedangkan yang dimaksud dengan factor teknis operasional antara lain Bandar udara untuk keberangkatan dan tujuan tidak dapat digunakan operasioanl pesawat udara, lingkungan menuju bandara atau landasan terganggu fungsinya disebabkan karena retak, banjir, atau kebakaran. Teknios operasional lainnya dapat juga disebabkan karena terjadinya antrian pesawat udara take off maupun landing, atau departure slot time atau juga disebabkan karena refueling.

\section{Hak Hak Konsumen dalam Pengangkutan Udara:}

a. Hak Pelayanan Yang Baik;

Pasal 134 Undang-undang Nomor 1 Tahun 2009 Tentang penerbangan dengan tegas memberikan hak pelayanan khusus berupa perlakuan dan fasilitas khusus bagi penyandang cacat, lanjut usia, anak-anak di bawah 12 (dua belas) tahun, dan orang sakit dari badan usaha angkutan udara. Pelayanan minimal fasilitas dan pelayanan khusus tersebut secara rinci disebutkan dalam Pasal 134 ayat (2) Undang-undang Nomor 1 Tahun 2009 Tentang Penerbangan. Uraian mengenai fasilitas khusus tersebut menjadi acuan peneliti dalam melaksanakan penelitian dan hasilnya diuraikan sebagai berikut:

1. Pemberian prioritas tambahan tempat duduk bagi penyandang cacat, orang lanjut usia, anak-anak dibawah umur 12 (dua belas) tahun, dan untuk orang sakit. Fasilitas ini tidak ditemukan di dalam pesawat udara pada penerbangan domestik. Penyandang cacat seperti penumpang yang tidak dapat berjalan kaki pada saat embarkasi dan disembarkasi hanya dibantu menggunakan kursi roda yang didorong oleh petugas maskapai. Kursi khusus yang ditentukan peraturan perundang-undangan tidak ditemukan di dalam pesawat udara, bahkan untuk dapat duduk di tempat yang membantu kemudahan bagi penumpang penyandang cacat, biasanya atas keikhlasan dari penumpang pesawat yang lain memberikan tempat duduknya digunakan oleh penumpang penyandang cacat tersebut. Selama penelitian, peneliti tidak menemukan adanya koordinasi antara 
petugas maskapai yang melayani chekin dengan keluarga penumpang penyandang cacat tersebut agar diberikan seat yang memudahkan bagi penyandang cacat tersebut. Orang lanjut usia oleh Undang-undang Nomor 1 Tahun 2009 mendapatkan prioritas tempat duduk di dalam pesawat udara tidak ditemukan dalam penerbangan domestik di Indonesia. Penumpang lanjut usia bahkan seringkali diberikan tempat duduk di bagian belakang pesawat udara, yang tentu saja kondisi tempat tersebut kurang nyaman bagi penumpang lanjut usia disebabkan karena jenis pesawat udara yang beroperasi di Indonesia lebih banyak menggunakan jenis Boeing dan Airbus yang mesinnya berada di bagian belakang pesawat sehingga menyebabkan suara bising mesin pesawat cukup mengganggu penumpang.

Penumpang anak-anak di bawahusia 12 (duabelas) tahun yang seharusnya mendapatkan pelayanan tempat duduk khusus di dalam pesawat diperlakukan sama dengan orang dewasa, Cumayangmembedakannyabahwa anak-anakdibawah3(tiga)tahun diberikan sabuk pengaman tersebdiri, selebihnya fasilitas sama, termasuk harga tiket untuk anakanak di atas 2 (dua) tahun sama dengan harga tiket orang dewasa, sedangkan harga tiket untuk anak-anak di bawah 2 (dua) tahun harus dibayar setengah dari harga tiket orang dewasa.

Sedangkan mengenai fasilitas khusus seperti tempat duduk khusus untuk orang sakit untuk penerbangan domestik di Indonesia tidak disediakan. Untuk orang sakit yang menggunakan tempattidurdorong disebabkankarenakondisiyangtidakmemungkinkan untuk duduk, maka penumpang yang sakit tersebut tidak akan diangkut oleh maskapai penerbangan regular, tetapi mereka harus mencarter pesawat udara dari dan ke tempat tujuan.

2. Penyediaan fasilitas kemudahan untuk naik ke dan turun dari pesawat udara; fasilitas semacam ini di semua pesawat udara pada penerbangan domestik tidak diketemukan, mungkin karena disebabkan jenis pesawat udara yang beroperasi di Indonesia tidak dilengkapidenganfasilitaskhususuntuknaikkedanturundaripesawatudara. Penumpang pesawat udara penyandang cacat, seperti penumpang yang tidak dapat berjalan ketika hendaknaik dan turun daritangga pesawatudara, maupun ketika menggunakan garbarata (belalai gajah), penumpang yang tidak dapat berjalan tersebut dibopong oleh petuas maskapai untuk didudukkan di atas seat penumpang dan demikian juga sewaktu hendak turun daripesawatpenumpangtersebut dibopongolehpetugasmaskapaidan didudukkan di atas kursi roda dan selanjutnya didorong menuju keluar gedung kedatangan.

3. Penyediaan fasilitas untuk penyandang cacat selama berada di dalam pesawat udara; semua pesawat udara yang beroperasi di Indonesia tidak memiliki fasilitas khusus di dalam pesawat bagi penyandang cacat. Ini disebabkan karena jenis pesawat udara yang beroperasi di Indonesia tergolong jenis pesawat udara menengah karena jumlah seat satu pesawat saja paling banyak 210 seat yakni jenis Boeing 900 ER. Jenis pesawat komersiil yang beroperasi di Indonesia hamper seluruhnya untuk kepentingan bisnis semata, oleh karena itu jumlah seatnyapun dibuat sedemikian rupa agar dapat menampung penumpang dalam jumlah yang banyak, tanpa memperhatikan fasilitas khusus yang telah ditentukan peraturan perundang-undangan.

4. Sarana bantu bagi orang sakit; bagi penumpang yang sakit keras, tidak ada sarana bantu khusus yang terdapat di dalam pesawat komersiil di Indonesia. Sama halnya dengan penumpang cacat, lanjut usia, tidak disediakan sarana khusus sebagaimana layaknya perintah peraturan perundang-undangan. Apabila penumpang yang sakit tersebut menghendaki untuk diberangkatkan dengan menggunakan fasilitas khusus, 
maka penumpang tersebut harus mencarter sendiri pesawat, yang tentu saja biayanya sangat mahal.

5. Penyediaan fasilitas untuk anak-anak selama berada di dalam pesawat udara; untuk penumpang anak-anak di bawah usia 12 (dua belas) tahun tidak ditemukan fasilitas khusus selama di dalam pesawat udara. Fasilitas yang ada adalah bagi penumpang di bawah usia 2 (dua) tahun diberikan menggunakan sabuk pengaman kecil yang terpisah dari sabuk pengaman yang ada di setiap seat penumpang. Setelah pesawat sampat di tujuan, maka sabuk pengaman khusus tersebut dikembalikan lagi ke petugas pesawat udara.

6. Tersedianya personel yang dapat berkomunikasi dengan penyandang cacat, lanjut usia, anak-anak, dan/atauorang sakit; untukpenumpangpenyandang cacat,lanjutusiamaupun anak-anak di bawah usia 12 (dua belas) tahun tidak disediakan personel khusus yang dapat berkomunikasi dengan mereka. Penumpang-oenumpang yang disebutkan di atas apabila bepergian dengan menggunakan pesawat udara, maka ia harus didampingi oleh keluarganya, atau petugas medis seperti dokter dan perawat yang menjadi tanggungan penumpang itu sendiri.

7. Tersedianya buku petunjuk tentang keselamatan dan keamanan penerbangan bagi penumpang pesawat udara dan sarana lain yang dapat dimengerti oleh penyandang cacat, lanjutusia. Bukupetunjuktentang keselamatan dankeamananpenerbangansecara umum disediakan di dalam pesawatyang terdapat di setiap seat penumpang. Krupesawat memperagakanbagaimanamenggunakansabukpengaman, masker, danpelindungwaktu kecelakaan.

\section{b. Hak Mendapatkan Ganti Rugi Jika Mengalami Kerugian}

Penumpang pesawat udara di Indonesia menurut Undang-undang Nomor 1 Tahun 2009 Tentang Penerbangan diberikan hak mendapatkan ganti rugi apabila mengalami kerugian. Pasal 141 ayat (1), Pasal 146 dan Pasal 147 Undang-undang Nomor 1 Tahun 2009 memerintahkan kepada setiap maskapai untuk bertanggung jawab atas kerugian yang diderita penumpang dalam hal:

1. Penumpang meninggal dunia; tindak lanjut dari ketentuan Pasal 141 (1) Undangunang Nomor 1 Tahun 2009 Tentang Penerbangan ini, Menteri Perhubungan Republik Indonesia mengeluarkan Peraturan Menteri Nomor 77 Tahun 2011 Tentang Tanggung Jawab Pengangkut Angkutan Udara. Dalam peraturan menteri ini, apabila penumpang meninggal dunia di dalam pesawat disebabkan karena kecelakaan pesawat udara, maka mendapatkan ganti rugi sebesar Rp 1.250.000.000,- (satu milyar dua ratus lima puluh juta rupiah). Dalam prakteknya, ganti kerugian tersebut diberikan oleh pihak pengangkut udara kepada ahli waris korban dengan prosedur yang sangat berbelit dan waktu yang cukup lama. Contoh kasus adalah kecelakaan pesawat udara Air Asia Indonesia kode penerbangan QZ 8501 route Bandara Juanda Surabaya menuju Changi Airport Singapura pada pukul 07.55 Waktu Indonesia Barat tanggal 28 Desember 2014. Proses ganti kerugian bagi penumpang yang meninggal dunia sampai saat ini belum selesai dilakukan oleh pihak Air Asia Indonesia. Dalam pemberian ganti kerugian sebesar Rp 1.250.000.000,- (satu milyar dua ratus lima puluh juta) rupiah tersebut, pihak pengangkut udara tidak dapat mengelak, karena Pasal 141 (1) Undang-undang Nomor 1 Tahun 2009 menerapkan Prinsip Tanggung Gugat Mutlak. Dengan demikian maka pihak pengangkut harus membayarkan ganti kerugian bagi penumpang yang meninggal dunia.

2. Penumpang cacat tetap; penumpang yang mengalami cacat tetap total oleh dokter dalam jangka waktu paling lambat 60 (enam puluh) hari kerja sejak terjadinya kecelakaan 
pesawat udara mendapatkan ganti kerugian sebesar Rp 1.250.000.000,-(satu milyar dua ratus lima puluh juta) rupiah. Cacat tetap total disini seperti kehilangan penglihatan total dari dua mata yang tidak dapat disebuhkan, atau terputusnya dua tangan atau dua kaki atau satu tangan dan satu kaki atau diatas pergelangan tangan atau kaki, atau kehilangan penglihatan total dari satu mata yang tidak dapat disembuhkan dan terputusnya satu tangan atau kaki di atas pergelangan tangan atau pergelngan kaki.

Sedangkan bagi penumpang yang dinyatakan cacat tetap sebagian oleh dokter dalam jangka waktu paling lambat 60 (enam puluh) hari kerja sejak terjadinya kecelakaan pesawatudara diberikan gantikerugian bervariasitergantung daricacatyang dideritanya. Ketentuan ini sampai dengan tulisan ini dibuat belum ada kecelakaan pesawat udara yang penumpangnya selamat.

3. Penumpang luka-luka; penumpang yang mengalami luka-luka dan harus menjalani perawatan di rumah sakit, klinik atau balai pengobatan sebagai pasien rawat inap atau rawat jalan diberikan ganti kerugian sebesar biaya perawatan yang nyata paling banyak Rp 200.000.000,- (dua ratus juta rupiah). Dalam praktek, belum ada penumpang yang mengalami keadaan seperti ini, karena sejak dikeluarkannya Peraturan Menteri Perhubungan Nomor 77 Tahun 2011 di Indonesia belum pernah terjadi kecelakaan pesawat udara yang penumpangnya selamat. Pemberian ganti kerugian kepada korban kecelakaan pesawat udara di Indonesia sangat berbelit-belit, sebagai contoh adalah korban kecelakaan pesawat udara Air Asia yang jatuh di Selat Karimata pada tanggal 28 desember 2014 sampai dengan saat sekarang ini belum seluruh korban menerima ganti kerugian dari pihak Air Asia.

4. Penumpang mengalami keterlambatan; dalam praktek, penumpang yang mengalami keterlambatan lebih dari 4 (empat) jam diberikan ganti kerugian sebesar Rp 300.000,(tiga ratus ribu) rupiah. Namun demikian, uang tersebut oleh maskapai ada yang diberikan tunai, ada juga yang diberikan dalam bentuk transfer ke rekening atas nama penumpang. Pemberian dengan cara transfer ke rekening atas nama penumpang ini sangat merugikan penumpang karena belum ada realisasi dari cara ganti kerugian semacam ini.

Kerugian penumpang yang mengalami keterlambatan kurang dari 4 (empat) jam dalam praktekselamainiadalahapabilaketerlambatanitukurangdarisatujam,makapenumpang mendapatkan makanan dan minuman ringan, sedangkan jika keterlamabatan tersebut lebih dari satu jam dan kurang dari tiga jam, setiap penumpang mendapatkan konsumsi berupa makanan (nasi kotak) dan minum.

Alasanyang dikemukakan selama inioleh pihakmaskapaiadalahketerlambatan tersebut disebabkan karena faktor cuaca dan/atau disebabkan karena teknis operasional.

5. Pembatalan penerbangan; untuk kerugian disebabkan karena pembatalan penerbangan selama ini disebabkan karena faktor alam seperti erupsi gunung meletus, factor asap yang mengakibatkan jarak pandang terbatas sehingga terjadi pembatalan penerbangan. Penumpang diberikan pilihan yakni, dikembalikan seluruh harga tiket, atau menunggu penerbangan padawaktuyang belumpasti. Bagipenumpangyangmemilihmengalihkan keberangkatan dengan menggunakan moda angkutan campuran seperti sebagian menggunakan moda angkutan darat, laut dan udara, maka sepenuhnya menjadi tanggungan pihak pengangkut udara.

\section{KESIMPULAN}

Peraturan perundang-undangan mengenai pelayanan yang baik kepada penumpang yang cacat, lanjut usia, anak dibawah usia 12 (dua belas) tahun serta orang sakit untuk mendapatkan 
fasilitas khusus dari badan usaha penerbangan tidak dijumpai dalam pengangkutan udara domestik di Indonesia. Prosedur mendapatkan ganti kerugian kepada penumpang yang meninggal dunia sebagai akibat kecelakaan pesawat udara di Indonesia sangat berbelit-belit. Ganti kerugian kepada penumpang pesawat udara di Indonesia yang disebabkan karena keterlambatan belum optimal diterapkan, terutama terhadap pemberian ganti kerugian sebagai akibat keterlambatan pemberangkatan lebih dari empat jam.

\section{DAFTAR PUSTAKA}

\section{Buku}

Az Nasution.(1999). Perlindungan Konsumen, Suatu Pengantar. Jakarta: Daya Widya.

Endang Saefullah Wiradipradja.(1989). Tanggung Jawab Pengangkut dalam Hukum Pengangkutan Udara Internasional dan Nasional. Yogyakarta: Liberty.

Martono.(2007). Kamus Hukum dan Regulasi Penerbangan. Jakarta: Raja Grafindo Persada.

Mukti Fajar dan Yulianto Achmad.(2010). Dualisme Penelitian Hukum, Normatif \& Empiris. Yogjakarta: Pustaka Pelajar.

Peter Mahmud Marzuki.(2008). Penelitian Hukum. Jakarta: Kencana Prenada Media Group.

Sudiarto.(2012). "Tanggung Gugat Pemerintah Terhadap Kecelakaan Pesawat Udara di Indonesia" Jurnal Ilmu Hukum Universitas Hassanuddin Makassar Amanna Gappa, 20(3):273.

Sidharta.(2000). Hukum Perlindungan Konsumen Indonesia. Jakarta: PT. Grasindo.

Sudiarto.(2012). “Tanggung Gugat Pengangkut Terhadap Penumpang Dalam Kecelakaan Pesawat Udara Pada Penerbangan Domestik" Universitas Airlangga Disertasi.

Yusuf Shofie.(2009). Perlindungan Konsumen \& Instrumen Instrumen Hukumnya. Bandung: Citra Aditya Bakti.

\section{Peraturan Perundang Undangan}

Pasal 147 ayat (2) Undang-undang Nomor 1 Tahun 2009 Tentang Penerbangan

Undang-undang Nomor 1 Tahun 2009 Tentang Penerbangan Lembaran Negara Republik Indonesia Tahun 2009 Nomor 1; Tambahan Lembaran Negara RepublikIndonesia Nomor 4956.

Undang-undang Nomor 8 Tahun 1999 Tentang Perlindungan Konsumen, Lembaran Negara Republik Indonesia Tahun 1999 Nomor 42; Tambahan Lembaran Negara Republik Indonesia Nomor 3821.

Peraturan Menteri Perhubungan Nomor 77 Tahun 2011 Tentang Tanggungjawab Pengangkut Angkutan Udara.

Putusan Mahkamah Agung Republik Indonesia Nomor 231/Pdt.G/2011/PN.Jkt.Pst 